UDC: 378.1

DOI: $10.15587 / 2519-4984.2020 .200468$

\title{
METHODOLOGICAL DEVELOPMENT OF EDUCATOR'S INFORMATION AND COMMUNICATION MOBILITY AS ADAPTIVE ABILITY OF EDUCATIONAL AND DEVELOPING E-ENVIRONMENT SELF-ORGANIZATION
}

\author{
L. Familiars'ka, L. Kloyts
}

\begin{abstract}
Явище глобалізації та активне використання можливостей інформаційно-комунікаційних технологій впливає на сочіальну атмосферу та економічну ситуацію в суспільстві. Відтак, актуалізовано иінність високого рівня інформаџійно-комунікачійної мобільності особистості, нових форм навчання, підвищення кваліфікачії і способів сучасної комунікачї у глобалізованому суспільстві. Метою дослідження є представлення методики розвитку інформаційно-комунікаційної мобільності у контексті підвищення особистісного потенціалу, інноваційності освітнього середовища, процесу трудової діяльності. Глобалізація ринку праці передбачає активне використання потенціалу освітнього е-середовища та є складовою різних моделей глобалізаиії.

У статті розкрито підходи до організачії розвитку фахівия в освітньому середовищі з використанням засобів інформаџійно-комунікаційних технологій. Позначено методичні підходи до розвитку мобільності педагога, як адаптивної здатності, щз суттєво впливає на швидкість адаптування особистості до зміни умов прачі у випадку трудової міграчії. Визначено інформачійно-комунікаційну мобільність, як адаптивну здатність самоорганізації освітнього е-середовищяа, ї̈ структуру, рівні.

Для проведення експериментальної роботи розроблено авторську програму розвитку адаптивної здатності педагога, яка передбачає підготовчий, діяльнісний, продуктивний етапи реалізації.

Навчально-методичний супровід реалізачї авторської методики розвитку інформаційно-комунікаційної мобільності педагога забезпечує розроблене електронне освітнє середовище.

В освітньому е-середовищі, передбачено збільшення можливостей для активності особистості, вироблення нових иляхів взаємодії в оточуючому середовищі, щзо представлене життєвими подіями, орієнтоване на забезпечення доступу дорослого до потоків знань, інструментальне оснащення і розширення власного освітнього простору, як складової неперервної освіти.

Комплексне використання теоретичних та емпіричних методів (тестування, бесіда, інтерв'ювання, самооцінювання) дозволило з'ясувати вихідний рівень інформаційно-комунікаційної мобільності, визначити вплив освітнього середовища післядипломної освіти на розвиток адаптивної здатності педагога та комплекс умов ї̈ розвитку. У дослідженні визначено особливості проектування освітнього середовища: неперервність, розвивальний характер навчання, відкритість.

Практичну значущістьь представляють розроблений комплекс інструментальних засобів діагностики розвитку інформаційно-комунікаційної мобільності в умовах андрагогічної освіти за основними ї̈ показниками та карта розвитку інформаційно-комунікаційної мобільності педагога. Їх застосування в умовах трудової міграції сприяє швидкому критичному самоаналізу і самоплануванню особистісно-професійних змін з використанням можливостей інформаційно-комунікаційних технологій.

Перспективи дослідження проблеми пов'язано з розробкою умов розвитку інформаційно-комунікаційної мобільності в е-середовищі інклюзивної освіти

Ключові слова: інформаційно-комунікаційна мобільність, освітнє е-середовище, адаптивна здатність, проектування освітнього середовища, андрагогічна освіта
\end{abstract}

Copyright $(\mathrm{C}) 2020$, L. Familiars'ka, L. Kloyts. This is an open access article under the CC BY license (http://creativecommons.org/licenses/by/4.0).

\section{Introduction}

The modern tendencies of the educational system reforming are conditioned by the development of society, which is characterized by upgrading of knowledge and ways of interaction of the communicational subjects [1,2].

At the same time, the topicality of this theme is determined by updated requirements to the professional activity of a specialist, which occurs under conditions of constant technological changes and revolutionary discov- eries in the field of informational and communicational technologies. It requires self-mobility of a personality in using the new communicational possibilities for his/her professional problems solving.

\section{Literary review}

Reorientation of the educational process in the questions of openness and mobility determines changes in the modern professional activity of the pedagogical 
workers, which is mostly determined by the level of informational and communicational mobility of a pedagogue, which development is carried out in the educational environment conditions of postgraduate education.

The theoretical analysis of psychological and pedagogical researches testified, that the Ukrainian scientists and the scientists from abroad consider the concept "mobility" in the following directions: as the characteristics of a specialist (reflectivity, creativity, projectivity, prognostication, goal setting, flexibility, plasticity) [3]; as an integrated quality of a personality and specific skills domination in fast adaptation according to changes, which are happening in society (adaptability, communicativity, independence, ability to adapt, purposefulness, denominational orientations and installations, social memory, critical intellection, self-discovery capacity, self-development, self-education) [4]; the aspects of social life and educational informatization (the practice of using mobile devices, the technologies of using different device types and their functional purpose) [5].

The mobility of a specialist, in general, is defined by researchers as a condition which allows to adapt to the dynamic and constant changes of conditions and means of professional activity. In the same time, the problem was studying in the aspect of pedagogical mobility [5, 6], informational mobility $[4,7]$, communicational mobility $[3,8]$.

Out of accord, the problem of informational and communicational mobility (IKM) of pedagogical workers, like an adaptive capacity of educational and developmental e-environment self-organization remained out of researches' attention.

\section{Objective and tasks of research}

The purpose of the article is to determine the structure and the levels of informational and communicational mobility of a pedagogue and characterize the methodology of pedagogical worker's informational and communicational mobility development.

The tasks of the research:

1. Put the state of the developed problem of specialist's informational and communicational mobility in postgraduate education through the theoretical analysis.

2. Determine the essential characteristics of pedagogical informational and communicational mobility and their structural components.

3. Characterize the methodology of pedagogue's informational and communicational mobility development in the postgraduate educational environment.

\section{Materials and methods of research}

The theoretical analysis of psychologicalpedagogical researches testified, that the scientists are considering the concept "mobility" in the aspect of integrated quality of a personality and enjoyment of individual skills which help to adapt quickly corresponding to the changes, happening in the world $[3,4]$.

In our research we determined informational and communicational mobility as an adaptive capacity of self-organization in the educational e-environment.

Under the term "an adaptive ability of a pedagogue" we understand an integral formation of interdependent components (cognitive-personal, evaluativecognitive, socio-active), where the reflexive mechanisms create a special cognitive experience, which provides the effective development of pedagogue's ICM [9].

Each of the structural components has the specific indicators, which determine ICM's development in the educational environment of professional activity and in general formed self-concept of pedagogue's ICM [10].

We could determine educational environment of postgraduate education as a set of conditions, which provide educational interaction and pedagogue's professional development with taking into account its needs, opportunities in accordance with the requirements of educational qualification characteristics.

We find out, that at the first stage of development of education, there takes place an integration of traditional and e-learning education, because the use of informational and communicational technological opportunities allows the organization of the learning process, invariant to the location and time of its participants, synchronous or asynchronous construction of an individual trajectory of its development $[11,12]$.

We understand the concept of pedagogue's informational and communicational mobility development in postgraduate education as a specialist's adaptation to the computer-mediated interaction in the environment of educational and professional activity, which characterize the pedagogue's movement from the lower to the higher level of informational and communicational mobility.

The author's technique of teacher's adaptive activity development, which includes a system of specific organization of the educational process, the basis of which is principles, methodological approaches which provide gradual teacher's ICM development from the intuitive-reproductive (low) to the creative-search (high) level of ICM, the specificity of this process and the conditions of its development activation in the postgraduate educational environment is worked out $[9,11]$.

The created educational e-environment provided the magnification of opportunities for personality's activity, produced the new ways of interaction with the environment, orientation on providing access of adults to the flow of knowledge and expanding own educational space, as a component of continuing education.

The method of exploratory mobility development was implemented in the municipal institution "Zhytomyr regional institute of postgraduate education" of the Zhytomyr regional council. 180 pedagogues of different qualification categories and different directions of teaching in the institution of general secondary education participated in the research, including 24 scientific and pedagogical workers of the institute.

The training was conducted in the time of coursework ( 6 hours of auditorium work and 30 hours of individual work) and in the inter-course period (108 hours of individual work with the methodological support), which is important in the process of teacher's uninterrupted development.

The method provided the implementation of the totality of active educational methods (case-method, educational training, mutual evaluation, mutual review) and differentiated forms of learning (master class, discussion, online conference), using informational and communicational technologies opportunities (electronic educational 
environment), and also realization of individual strategies of education. The teacher's ICM development is a long process of gradual (slow) transition from ignorance to knowledge, from some skills improving to mastering others (Fig. 1).

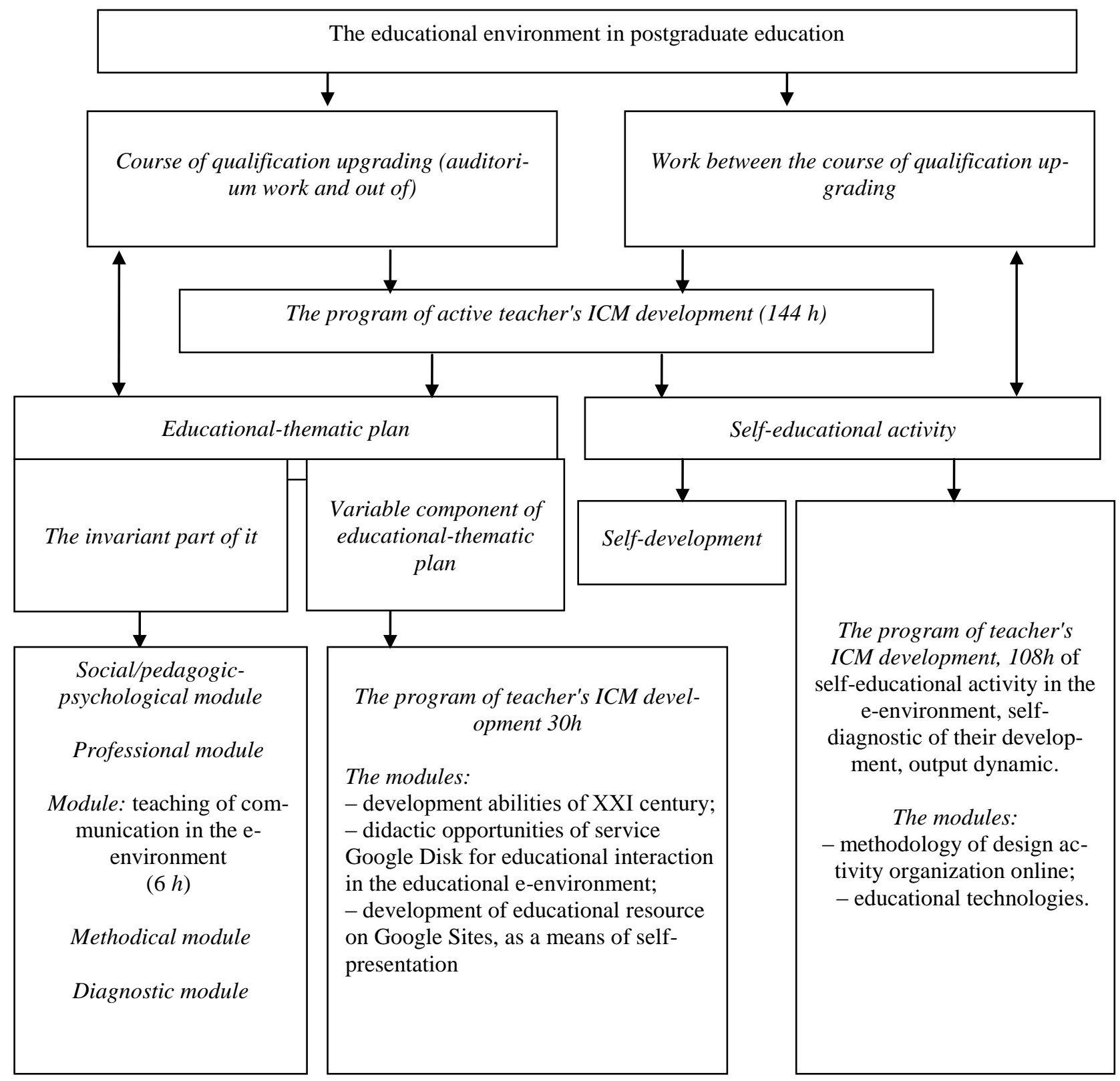

Fig. 1. The structural model of implementation of the informational and communicational development in the educational program of postgraduate education

In our opinion it's advisable to form the content of an educational program of pedagogue's qualification improvement, considering the principles:

- fundamental knowledge of ICM's development, systematization and mastering of forms, methods of pedagogical work in the educational environment with using communicational means opportunities;
- understanding of the ways of their integration with the traditional teaching in the process of teacher's qualification preferment.

The methodology of ICM's development of a teacher is implemented in stages: preparatory, active, productive. Every stage of program is its object, tasks, conditions, features of organization of the developmental environment, expected results (Fig. 2). 


\begin{tabular}{|c|c|c|c|c|c|c|c|c|c|c|}
\hline 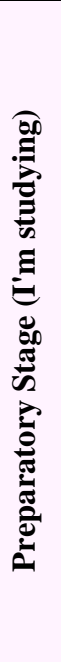 & & $\begin{array}{l}\text { I'm - } \\
\text { achievements in } \\
\text { the professional } \\
\text { activity, } \\
\text { organization of } \\
\text { constructive and } \\
\text { subjective } \\
\text { interaction, } \\
\text { positive } \\
\text { motivation to } \\
\text { interaction in the } \\
\text { e-environment. }\end{array}$ & & $\begin{array}{l}\text { Acquiring knowledge } \\
\text { to create the new } \\
\text { professional } \\
\text { experience. Creation } \\
\text { of conditions of } \\
\text { awareness of the } \\
\text { possibilities of "self- } \\
\text { achieving". }\end{array}$ & & $\begin{array}{l}\text { Needs of a } \\
\text { teacher in } \\
\text { getting the } \\
\text { new } \\
\text { professional } \\
\text { experience, } \\
\text { voluntary } \\
\text { participation in } \\
\text { the online } \\
\text { community. }\end{array}$ & & $\begin{array}{l}\text { Common activity, } \\
\text { aimed at self- } \\
\text { discovery, self- } \\
\text { organization, } \\
\text { positive attitude to } \\
\text { things that happen. }\end{array}$ & & $\begin{array}{l}\text { Gaining of the new } \\
\text { experience, } \\
\text { participation in the } \\
\text { professional online } \\
\text { community. } \\
\text { Mastering of the } \\
\text { new experience. } \\
\text { The condition of } \\
\text { self-evaluation. }\end{array}$ \\
\hline 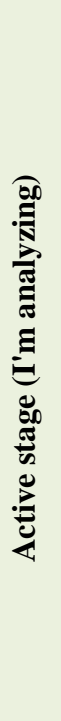 & 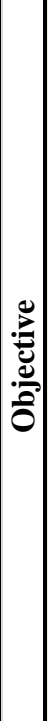 & $\begin{array}{l}\text { Engaging in } \\
\text { educational } \\
\text { activity of } \\
\text { teacher's online } \\
\text { community, self- } \\
\text { esteem, self- } \\
\text { regulation of } \\
\text { professional } \\
\text { activity, } \\
\text { possibility of } \\
\text { using the } \\
\text { educational e- } \\
\text { environment. }\end{array}$ & is & $\begin{array}{l}\text { Appraisal of } \\
\text { interaction and } \\
\text { belonging to the } \\
\text { professional } \\
\text { community, self- } \\
\text { regulation, comparing } \\
\text { yourself with the } \\
\text { significant others. }\end{array}$ & 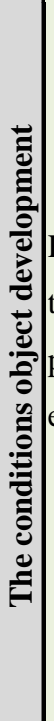 & $\begin{array}{l}\text { Reflection of } \\
\text { the educational } \\
\text { process in the } \\
\text { e-environment. }\end{array}$ & 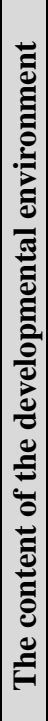 & $\begin{array}{l}\text { Dialogue and } \\
\text { mutual assistance } \\
\text { of the online } \\
\text { community of } \\
\text { specialists, mutual } \\
\text { reflection of the } \\
\text { problematic } \\
\text { situation. }\end{array}$ & 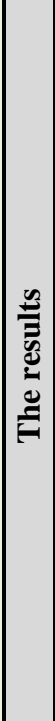 & $\begin{array}{l}\text { Development of } \\
\text { individual and } \\
\text { mutual products. } \\
\text { Professional } \\
\text { perseverance, } \\
\text { adequate self- } \\
\text { esteem. The } \\
\text { condition of self- } \\
\text { regulation. }\end{array}$ \\
\hline 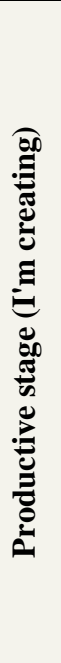 & & $\begin{array}{l}\text { Ability to } \\
\text { streamline } \\
\text { educational } \\
\text { interaction in the } \\
\text { e-environment, } \\
\text { build initiative } \\
\text { social activity } \\
\text { using e-content, } \\
\text { organize the } \\
\text { personalized } \\
\text { educational } \\
\text { environment. }\end{array}$ & & $\begin{array}{l}\text { Create the conditions } \\
\text { for self-improving, } \\
\text { cooperation in the } \\
\text { pedagogical } \\
\text { community, } \\
\text { rationalization of } \\
\text { professional activity. }\end{array}$ & & $\begin{array}{l}\text { Cooperation } \\
\text { inside the } \\
\text { pedagogical } \\
\text { online } \\
\text { community. }\end{array}$ & & $\begin{array}{c}\text { Support of the } \\
\text { author productive } \\
\text { activity of a } \\
\text { pedagogue. }\end{array}$ & & \begin{tabular}{|c|}
$\begin{array}{c}\text { Mobility of self- } \\
\text { actualization, of } \\
\text { educational }\end{array}$ \\
interaction in the e- \\
environment, \\
building of \\
proactive social \\
activity with the use \\
of the personalized \\
educational \\
environment.
\end{tabular} \\
\hline
\end{tabular}

Fig. 2. The characteristics of the methodology of the gradual development of teacher's ICM

In this program, interaction it's a building of the subject-subjective level, providing an integration of emotionally-valuable and professional-personal experience of their members with the help of taking part in different types of e-communication.
The developed electronic educationaldevelopmental environment provides the educationalmethodological support of the author's methodology of ICM's development of teacher's realization, considering an experience, needs and interests of a teacher: 
- detecting of the available level of the motivational development in informational and communicational mobility;

- realization of didactic testing to determine the level of the cognitive-personal component of informational and communicational mobility "the level of knowledge and mobilities";

- revealing a questionnaire of the socialdemographic indicators of the respondents (age, education, qualification, pedagogical rank, experience of pedagogical work, place of living) to determine the objectivity and characteristics of the problem, determine ideas of informational and communicational mobility, personal attitude to the problem, needs for improvement, development conditions of informational and communicational mobility etc;

- componential analysis of the messages from the participants of the online community;

- componential analysis of the results of the independent work and the work in group.

The features of the educational environmental project (Fig. 3) are continuity, multilevel type, developmental characteristics of education, self-realization, selfcontrol.

\begin{tabular}{|c|c|}
\hline & Module \\
\hline Ed & $\begin{array}{c}\text { ucational communication in the e-environment: approaches to planning and } \\
\text { organization of the modern educational process }\end{array}$ \\
\hline$\dot{0}$ & Module information \\
\hline : & Purpose, expected results, features of training organization \\
\hline$\sqrt[5]{5}$ & Lecture materials \\
\hline & $\sim \quad$ Lecture notes \\
\hline & Video lectures and interactive materials \\
\hline & Practical work \\
\hline & $\quad$ List of sources and additional materials \\
\hline ים & Current testing \\
\hline 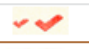 & Final testing \\
\hline$\varnothing$ & Forum \\
\hline 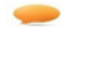 & Forum - Task "Google Calendar Features as a Tool for Effective Engagement Planning" \\
\hline 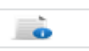 & Essay requirements \\
\hline$\because$ & Review Requirements (Mutual Review) \\
\hline & Requirements for evaluation (mutual evaluation) \\
\hline & Additional literature and materials \\
\hline
\end{tabular}

Fig. 3. The fragment of the educational module content in the developed e-environment

As it was noted, it's important to take into account that the subjects of the educational process in the system of qualification preferment are adults: workers of the institute of postgraduate education and pedagogues of the schools.

The success of the interaction is conditioned by the principles of educational process implementation, considering the level of informational and communicational mobility of their specialty and qualification category.

Accordingly, the active use of informativecommunicative technologies and their possibilities, preferment of an adaptive potential level of the modern personality predetermine the modern challenges. The high level of specialist's ICM, as an adaptive ability, affects the speed of his/her adaptation to the changes of working conditions in the case of labor migration.

\section{Results of research and their discussion}

The generalization of the results of education of the teachers found out, that $84 \%$ participants noted, that in the process of work they could see their work from the other side, and it gave the possibility to see it in a new way, to made up the special opinion of the advantages and disadvantages of their professionalism; $64 \%$ noted, that they started to understand better an experience of their own activity in the way of studying and perceiving an experience of theirs colleges, correlating with own experience; $60 \%$ are sure, that they can use possibilities of e-environment and e-contents for the renewal ways of their professional activity; $48 \%$ thought, that they could see more clear the perspectives of their own activity and they were ready to improve it.

The experiment noted the positive changes in the indexes of levels of informational and communicational mobility. The proposed methodology, adapted to the market requirements, based on an integration of traditional and innovative forms of education, taken into account the specificity of adult's education, can be updated according to objective circumstances.

The results show the positive influence of teacher's participation in the proposed events, demonstrating positive changes in all components of informational and communicational mobility of the pedagogues (cognitivepersonal, social-active, evaluative-reflexive).

The result of the implemented program is the development of the ICM's level, open cognitive position of a pedagogue; it's necessity of continue the professional development in the conditions of society globalization.

The practical significance of using the designed complex of tools of developmental diagnostic of informational and communicational mobility in the conditions of andragogical education and of the development card of informational and communicational mobility of a pedagogue in the research is about gaining skills of the fast critical introspection and self-planning, self-professional changes with using the possibilities of the informative- 
cognitive technologies, that can be a condition of labor migration prevention.

\section{Conclusions}

Implementation of the theoretical analysis of the development state of the problem shows that the dominant in the concept of interpretation of the nature of different types of mobility is an idea of adaptation, flexibility and speed of reaction to the changes of conditions of professional activity. The development of informational and communicational mobility of a specialist in postgraduate education as a self-characteristic, it's a condition of adaptation, social transformations, self-development of a subject of activity in the conditions of the modern labor market.

Based on the main scientific approaches to understand the concept of mobility and natural characteristics of its structural components, we gave the characteristics for this concept as an inter-system interdependence of the three substructures: cognitive-personal, the criterion of which is information about own knowledge, skills (an adequacy of self-concept, I-image); reflexive-evaluative, the criterion of which is the reflexivity of efficiency of activity (self-esteem, self-activity, performance of activity); social-active, the criterion of which is the communi- cation at interaction of subjects of the educational process (self-development, adaptability to the changes of working conditions).

The one of specific features of teacher's ICM is that it does not depend on changes of the place of work and it proposes the changes in organization of the educational-developmental environment of professional activity.

The methodology of development of teacher's ICM, taking into account certain stages (preparatory, active, productive), is built on the didactic bases: purpose, content, tasks, conditions, content of the developmental environment, results, analysis of their efficiency.

Realization of the presented methodology in postgraduate education provides an improvement of the selfpotential, an innovation of the educational environment and professional activity in the process of informational and communicational mobility of a personality in accordance with the modern economical requirements of society.

The outlined research doesn't show all aspects of the problem.

The perspective ways of the next research of the problem in the context of education and labor migration we see in the development of the e-environment of inclusive education.

\section{References}

1. Vinevskaya A. Using the potential of information technology to create a mobile learning environment // GESIS - Leibniz Institute for the Social Sciences: Koncept. 2012. Issue 9. URL: https://www.ssoar.info/ssoar/handle/document/32078

2. Mitchell W. J., Borroni-Bird C. E., Burns L. D. New Mobility Markets // Reinventing the Automobile: Personal urban mobility for the 21st century. Cambridge: The MIT Press, 2010. doi: http://doi.org/10.7551/mitpress/8490.003.0009

3. Algaev A. N. Communicative mobility in educator-psychologist's job description structure // Modern problems of science and education. 2012. Issue 6. P. 375-382.

4. Voronovskaya L. P. Structure of professional mobility of a utility sector specialist // Austrian Journal of Humanities and Social Sciences. 2015. Issue 7-8. P. 36-39. doi: http://doi.org/10.20534/ajh-15-7.8-36-39

5. Bykov V. Yu. Innovatsiinyi rozvytok zasobiv i tekhnolohii system vidkrytoi osvity // Suchasni informatsiini tekhnolohii ta innovatsiini metodyky u pidhotovtsi fakhivtsiv: metodolohiia, teoriia, dosvid, problemy. 2012. Issue 29. P. 32-40.

6. Bugaychuk K. L. Mobile learning: essence and models of introduction in educational process of higher educational establishments MIA OF Ukraine // Informatsiini tekhnolohii i zasoby navchannia. 2012. Vol. 27, Issue 1. URL: https://journal.iitta.gov.ua/index.php/itlt/article/view/619/480

7. Neliepova A. V. Metodyka formuvannia informatsiinoi mobilnosti maibutnikh ahronomiv-doslidnykiv: abstract $\mathrm{PhD}$ thesis. Kyiv, 2011.22 p.

8. Kuzminska O. H. Zabezpechennia umov nabuttia profesiinoi kompetentnosti pedahohiv v umovakh informatsiinoho suspilstva // Nova pedahohichna dumka. 2010. Issue 2. P. 107-111.

9. Antonova O. Y., Familiarska L. L. Study of the development of the teacher's information and communication mobility within the system of postgraduate education // Zhytomyr Ivan Franko State University Journal Pedagogical Sciences. 2019. Issue 1 (96). P. 58-65. doi: http://doi.org/10.35433/pedagogy.1(96).2019.58-65

10. Kloyts L. A. Study of developmentof professional self-definition of modern pedagogue // Aktualni problemy psykholohii. 2019. Vol. 4, Issue 15. P. 75-92.

11. Sorokina A. I. Psychological features of professional mobility of young specialists of the Russian Federation: Proceedings // Actual problems of studying of professional mobility and sense of justice of young professionals. 2013.73 p.

12. Weber M. Future Mobility: Interview with Robin Chase (Buzzcar, Paris) // Checkdisout. 2012. URL: http://checkdisout.com/2012/01/16/checkdisout-6-future-mobility-interview-with-robin-chase-buzzcar-paris/

Received date 17.12.2019

Accepted date 28.01.2020

Published date 25.05.2020

Larissa Familyarska, PhD, Department of Pedagogy and Andragogy, Communal Institution «Zhytomyr Regional Institute of Postgraduate Pedagogical Education» Zhytomyr Regional Council, Mykhailivska str., 15, Zhytomyr, Ukraine, 10014

Lybov Klots, PhD, Department of Psychology, Communal Institution «Zhytomyr Regional Institute of Postgraduate Pedagogical Education» Zhytomyr Regional Council, Mykhailivska str., 15, Zhytomyr, Ukraine, 10014 E-mail: lubanaklez@ukr.net 